\title{
STUDY PENGEMBANGAN PENDIDIKAN DAN PELATIHAN BAGI APARATUR SIPIL NEGARA BERBASIS IMPLEMENTASI MODEL $A D D I E$
}

\author{
Ketut Rusmulyani \\ BPSDM Provinsi Bali \\ Email: ochaketut@gmail.com
}

\begin{abstract}
Abstrak
Pengembangan Pendidikan dan Pelatihan Bagi Aparatur Sipil Negara memerlukan sebuah tahapan yang sederhana, mudah digunakan dan tentunya sistematis. Salah satu model pengembangan yang dapat digunakan adalah model Addie. Tujuan dari penelitian ini adalah untuk mengetahui tahap-tahap pengembangan Pendidikan dan Pelatihan Bagi Aparatur Sipil Negara dengan menggunakan model Addie serta untuk mengetahui implementasi model Addie pada Pendidikan dan Pelatihan bagi Aparatur Sipil Negara. Penelitian ini adalah penelitian yang bersifat studi pustaka (library research). Model Addie yang diterapkan pada penelitian ini mampu mengidentifikasi pengembangan Pendidikan dan Pelatihan bagi Aparatur Sipil Negara secara mendalam. Dari hasil penelitian ini juga menunjukkan kualitas pelatihan yang berlangsung selama ini sudah baik. Dengan demikian, pengembangan pelatihan perlu terus dilakukan. Namun bentuk pengembangannya perlu dikaji secara ilmiah, sehingga produk pengembangannya dapat menjadi solusi dalam memecahkan persoalan pelatihan.
\end{abstract}

Kata Kunci : Model Addie, Pengembangan, Diklat

\begin{abstract}
Development of Education and Training for State Civil Apparatuses requires a simple, easy to use, and certainly systematic stage. One development model that can be used is the Addie model. The purpose of this study is to determine the stages of development of Education and Training for State Civil Apparatuses using the Addie model and to determine the implication of the Addie model in Education and Training for State Civil Apparatus. This research is library research. The Addie model applied in this study was able to identify the development of Education and Training for State Civil Apparatuses in depth. The results of this study also showed that the quality of the training that had taken place so far had been good. Thus, the development of training needs to be continued. But the form of development needs to be studied scientifically so that its development products can be a solution in solving training problems.
\end{abstract}

Key Words: Addie model, Development, Education and Training

\section{PENDAHULUAN}

Di era globalisasi yang penuh persaingan ini, telah terjadi reformasi di berbagai bidang kehidupan sebagai konsekuensi dari pesatnya pembangunan ilmu pengetahuan dan teknologi. Reformasi pemerintahan yang terjadi di Indonesia telah mengakibatkan terjadinya pergeseran paradigma penyelenggaraan pemerintahan dari paradigma sentralistis ke arah desentralisasi yang ditandai dengan pemberian otonomi yang luas dan nyata kepada daerah. Peraturan Lembaga Administrasi Negara Nomor 2 Tahun 2019 tentang Pelatihan Kepemimpinan Nasional Tingkat II, melalui penetapan kebijakan pembaharuan pelatihan ini, diharapkan dapat menghasilkan alumni yang tidak hanya memiliki kompetensi, tetapi juga mampu menunjukkan kemampuan untuk membentuk kepemimpinan strategis dalam rangka menghadapi dinamika lingkungan organisasi dan mendorong perubahan organisasi yang berdampak bagi organisasi sesuai dengan tanggungjawab instansinya. Salah satu cara yang dapat dilakukan dalam upaya meningkatkan kinerja pegawai negeri sipil yaitu dengan melakukan pendidikan dan pelatihan [1]. Untuk mencapai kinerja yang diharapkan dalam suatu instansi, para pegawai negeri sipil harus mendapatkan program 
pendidikan dan pelatihan yang memadai untuk jabatannya [2].

Pelatihan yang bermutu dapat diwujudkan melalui usaha yang mampu mensinergikan seluruh komponen secara optimal. [3] menyatakan pendidikan dan pelatihan (Diklat) dikatakan bermutu, jika dapat melahirkan lulusan yang mampu menghadapi tantangan kehidupan yang dihadapinya.

Pendidikan dan pelatihan tidak hanya meningkatkan pengetahuan dan skill individu saja, namun dalam Diklat juga ditanamkan nilai-nilai yang berkaitan dengan ketaatan, loyalitas, dan kedisiplinan, sehingga sikap atau perilaku individu menjadi lebih baik. Sikap yang baik nantinya akan menghasilkan respon yang baik terhadap sesama pegawai negeri sipil maupun atasan, sehingga akan tercipta lingkungan kerja yang kondusif dan mampu meningkatkan motivasi pegawai negeri sipil dalam bekerja. Di samping itu juga, pegawai negeri sipil harus mempunyai sikap yang professional, berbudi pekerti luhur, berdaya-guna, berhasil-guna, sadar akan tanggung jawabnya sebagai unsur aparatur negara, abdi masyarakat, dan abdi negara dalam Negara Kesatuan Republik Indonesia.

Hal lain yang juga perlu diperhatikan seperti kebijaksanaan mengenai prioritas program dalam pendidikan dan pelatihan agar dapat meningkatkan dan memperbaiki kelemahan kinerja pegawai negeri sipil. Banyak faktor yang mempengaruhi prestasi kerja, faktor-faktor yang mempengaruhi prestasi kerja antara lain adalah : kepemimpinan, lingkungan kerja, disiplin kerja, motivasi kerja, pendidikan dan pelatihan kerja. Pendidikan dan pelatihan merupakan kunci dalam manajemen yang memainkan peran penting dan strategis dalam meningkatkan prestasi kerja [4].
Menurut [5] mengungkapkan seorang pegawai negeri sipil dituntut untuk memiliki kemampuan seperangkat pengetahuan dan keterampilan teknis di dalam sebuah proses pelatihan, di samping menguasai ilmu. Kualitas pelatihan yang berlangsung selama ini masih banyak menuai persoalan. Dengan demikian, pengembangan pelatihan perlu terus dilakukan. Namun bentuk pengembangannya perlu dikaji secara ilmiah sehingga produk pengembangannya dapat menjadi solusi dalam memecahkan persoalan pelatihan.

Hasil penelitian mengindikasikan sebagian besar lulusan pelatihan kurang mampu menyesuaikan diri dengan perubahan maupun perkembangan ilmu pengetahuan dan teknologi serta kurang bisa mengembangkan dirinya dengan kebutuhan masyarakat. Dengan demikian hasil temuan tersebut mengindikasikan bahwa kegiatan pelatihan yang dilaksanakan di berbagai instansi pemerintahan masih belum dapat menyentuh atau mengembangkan kemampuan dan potensi pegawai negeri sipil secara keseluruhan. [6] mengungkapkan peran pendidikan dan pelatihan menjadi penting dalam mengimplementasikan pelatihan bermutu yang mengarah kepada pemecahan persoalan. [7] dalam mengembangkan bahan pelatihan perlu diperhatikan model pengembangannya guna memastikan kualitas bahan pelatihan, karena pengembangan bahan pelatihan pada dasarnya merupakan proses yang bersifat linier dengan proses pelatihan. Ketersediaan bahan pelatihan selama ini masih minim. Bahan pelatihan semestinya disusun berdasarkan kebutuhan tujuan pelatihan. Salah satu desain pengembangan bahan pelatihan yang sering digunakan adalah model ADDIE melalui 5 tahapan yaitu: Analysis, Design, Development, Implementation dan Evaluation. 
Dari latar belakang di atas, penulis ingin mengetahui bagaimana tahap-tahap pengembangan Pendidikan dan Pelatihan bagi Aparatur Sipil Negara dengan menggunakan model Addie, serta bagaimana implementasi model Addie pada Pendidikan dan Pelatihan bagi Aparatur Sipil Negara?

\section{METODE}

Penelitian ini bersifat studi pustaka (library research). Pada bagian ini dilakukan pengkajian mengenai konsep dan teori yang digunakan berdasarkan literatur yang tersedia, terutama dari artikel-artikel yang dipublikasikan dalam berbagai jurnal ilmiah. Kajian pustaka berfungsi untuk membangun konsep atau teori yang menjadi dasar studi dalam penelitian. Kajian pustaka atau studi pustaka merupakan kegiatan yang diwajibkan dalam penelitian, khususnya penelitian akademik yang tujuan utamanya adalah mengembangkan aspek teoritis maupun aspek manfaat praktis. Sehingga dengan menggunakan metode penelitian ini penulis dapat dengan mudah menyelesaikan masalah yang hendak diteliti.

Sebelum melakukan telaah bahan pustaka, peneliti harus mengetahui terlebih dahulu secara pasti tentang dari sumber mana informasi ilmiah itu akan diperoleh. Adapun beberapa sumber yang digunakan antara lain: Keputusan Kepala Lembaga Administrasi Negara Tentang Kurikulum Pelatihan Kepemimpinan Nasional Tingkat II, buku-buku teks dan jurnal ilmiah.

Setelah keseluruhan data terkumpul, maka langkah selanjutnya penulis menganalisa data tersebut sehingga ditarik suatu kesimpulan. Untuk memperoleh hasil yang benar dan tepat dalam menganalisa data, penulis menggunakan teknik analisis isi. Analisis isi (Content Analysis) adalah penelitian yang bersifat pembahasan mendalam terhadap isi suatu informasi tertulis.

\section{HASIL DAN PEMBAHASAN}

Penggunaan model bahan pelatihan yang sesuai dengan teori akan menjamin kualitas bahan pelatihan. Model tersebut antara lain: model Addie, Assure, Hannafin and Peck, Gagne and Brigs, serta Dick and Carey. Dari model tersebut tentu memiliki karakteristik masingmasing yang perlu dipahami. Model intruksional Addie merupakan proses instruksional yang sudah umum digunakan baik secara tradisional oleh pengembang diklat. Ada lima frase yaitu analisis, desain, pengembangan, implementasi dan evaluasi yang mempresentasikan panduan perangkat pengembangan pelatihan dan kinerja yang dinamis. Bila digambarkan adalah sebagai berikut :

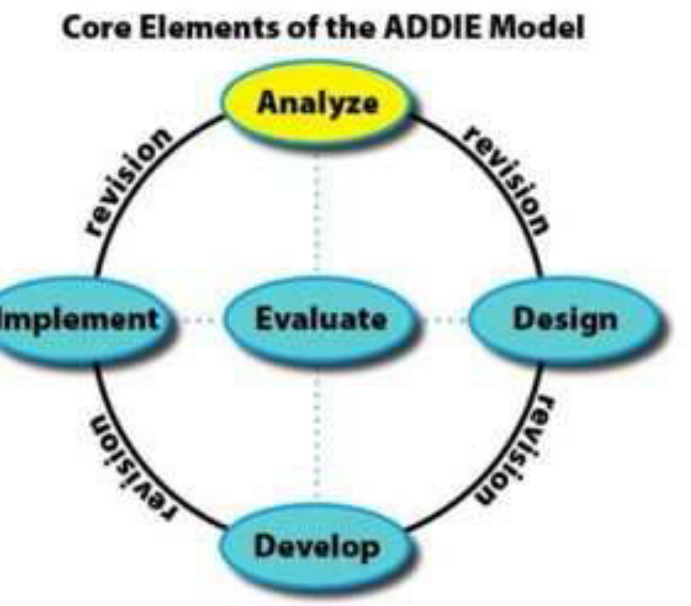

\section{Gambar 1. Tahap Pengembangan Model ADDIE (Sumber: [8])}

Model Addie menggunakan pendekatan sistem. Esensi dari pendekatan sistem adalah membagi proses perencanaan pelatihan ke beberapa langkah. Mengatur langkah-langkah ke urutan-urutan logis, kemudian menggunakan output dari setiap langkah sebagai input pada langkah berikutnya. Begitupun dengan pendapat [9] mengatakan bahwa model Addie merupakan model yang sangat sederhana 
dalam prosedurnya, tetapi implementasinya sistematis. Pembahasan mengenai setiap tahapan pada model ADDIE yaitu sebagai berikut : tahap (1) Analisis (Analysis). Dalam tahapan ini, kegiatan utama adalah menganalisis perlunya pengembangan bahan pelatihan, beberapa analisis yang dilakukan adalah sebagai berikut :

a. Analisis kinerja.

Dalam tahapan ini, mulai dimunculkan masalah dasar yang dihadapi dalam pelatihan, seperti pegawai/aparatur masih belum bekerja sesuai dengan bidang tugasnya atau tidak sesuai dengan bidang tugasnya hal itu disebabkan karena banyak pegawai yang belum menguasai bidang tugasnya masing- masing secara baik.

b. Analisis Peserta Pelatihan.

Analisis peserta Pendidikan dan Pelatihan bagi Aparatur Sipil Negara merupakan telaah karakteristik peserta berdasarkan pengetahuan, keterampilan dan perkembangannya. Analisis ini bertujuan untuk mengetahui tingkat kemampuan peserta Pendidikan dan Pelatihan bagi Aparatur Sipil Negara yang beragam. Hasil analisis peserta Pendidikan dan Pelatihan bagi Aparatur Sipil Negara berkenaan dengan kemampuan berpikir kritis dan kreatif dapat dijadikan gambaran dalam mengembangkan bahan pelatihan. Beberapa poin yang perlu didapatkan dalam tahapan ini di antaranya : (1) Karakteristik peserta Pendidikan dan Pelatihan bagi Aparatur Sipil Negara, (2) Pengetahuan dan ketrampilan yang telah dimiliki peserta Pendidikan dan Pelatihan bagi Aparatur Sipil Negara, (3)Kemampuan berpikir atau kompetensi yang perlu dimiliki peserta Pendidikan dan Pelatihan bagi Aparatur Sipil Negara, (4) Bentuk pengembangan bahan pelatihan yang diperlukan peserta
Pendidikan dan Pelatihan bagi Aparatur Sipil Negara agar dapat meningkatkan kemampuan berpikir dan kompetensi yang dimiliki.

c. Analisis fakta, konsep, prinsip dan prosedur materi pelatihan. Analisis materi berkenaan dengan fakta, konsep, prinsip dan prosedur merupakan bentuk identifikasi terhadap materi agar relevan dengan pengembangan bahan pelatihan. Dalam tahap ini, analisis dilakukan dengan metode studi pustaka. Tujuan dari analisis fakta, konsep, prinsip dan prosedur materi pelatihan adalah untuk mengidentifikasi bagian-bagian utama materi yang akan diajarkan dan disusun secara sistematik. Analisis ini dapat dijadikan dasar untuk menyusun rumusan tujuan pelatihan.

d. Analisis tujuan pelatihan. Analisis tujuan pelatihan merupakan langkah yang diperlukan untuk menentukan kemampuan atau kompetensi yang perlu dimiliki oleh peserta pelatihan. Pada tahap ini, ada berapa poin yang perlu didapatkan diantaranya : (a) Tujuan pelatihan yang telah ditentukan., (b) Ketercapaian tujuan pelatihan. Dengan demikian, tahapan ini dapat dijadikan acuan untuk mengembangkan bahan pelatihan.

Salah satu contoh diagnosa pada pelatihan ini membekali peserta dengan kompetensi mendiagnosa seluruh isu dalam organisasi, menentukan isu strategis unit organisasi, mengidentifikasi berbagai permasalahan yang menghambat kinerja unit organisasinya melalui penerapan teknikteknik analisis organisasi dan merumuskan solusi atau upaya mengatasinya untuk mencapai kondisi yang diharapkan. Setelah mengikuti pelatihan ini, peserta diharapkan mampu menentukan isu strategis terpilih sesuai unit organisasinya sebagai gagasan perubahan, memahami konsep diagnosa 
organisasi, dan teknik-teknik analisis organisasi untuk mendukung pelaksanaan tugas-tugasnya dalam mengendalikan pelaksanaan kegiatan pelayanan publik, administrasi pemerintahan dan pembangunan yang dilakukan para pelaksana di bawahnya. Tahap (2) Desain (Design), tahap ini meliputi beberapa perencanaan dalam pengembangan bahan pelatihan, di antaranya meliputi beberapa kegiatan sebagai berikut : (a) Penyusunan bahan pelatihan kontekstual dengan mengkaji kompetensi inti dan kompetensi dasar untuk menentukan materi pelatihan berdasarkan fakta, konsep, prinsip dan prosedur, alokasi waktu pelatihan, indikator dan instrumen penilaian peserta pelatihan. (b) Merancang skenario Pendidikan dan Pelatihan bagi Aparatur Sipil Negara, (c) Pemilihan kompetensi bahan Pendidikan dan Pelatihan bagi Aparatur Sipil Negara, (d) Perencanaan awal perangkat pelatihan yang didasarkan pada kompetensi materi Pendidikan dan Pelatihan bagi Aparatur Sipil Negara, (e) merancang materi pelatihan dan alat evaluasi Pendidikan dan Pelatihan bagi Aparatur Sipil Negara.

Contoh Struktur Design Kurikulum pada Pelatihan Bagi Aparatur Sipil Negara atau Pelatihan Kepemimpinan Nasaional (PKN Tk..II) sebagai berikut :

\section{Tabel 1: Agenda Kegiatan Pelatihan}

\begin{tabular}{lll}
\hline No. & \multicolumn{1}{c}{ Agenda/Mata Pelatihan } & JP \\
\hline \multirow{3}{*}{ Agenda Orientasi Program } & \\
2 & Pembukaan & 0 \\
& $\begin{array}{l}\text { Strategi Kebijakan Pengembangan } \\
\text { Kompetensi ASN }\end{array}$ & 3 \\
3 & Overview Kebijakan Pelatihan & 3 \\
4 & Dinamika Kelompok & 3 \\
5 & Kebijakan dan Tindak Lanjut & 3 \\
& Hasil Pelatihan & \\
& Agenda 1: Mengelola Diri & \\
1 & Energi Kepemimpinan & 6 \\
2 & Integritas Kepemimpinan & 9 \\
& Agenda 2: Kepemimpinan & \\
& Strategis
\end{tabular}

$1 \quad$ Organisasi Adaptif 9

2 Kepemimpinan Kewirausahaan 9

3 Organisasi Pembelajaran 6

Agenda 3: Manajemen Strategis

1 Dialog Strategis 9

2 Ceramah Isu Strategis: 15

Integritas kepemimpinan 3JP

Kepemimpinan kewirausahaan

(role model) 3JP;

Kebijakan nasional 3JP;

Sesuai Tema VKN 6JP.

3 Marketing Sektor Publik

Agenda 4: Aktualisasi

Kepemimpinan

1 Visitasi Agenda Pembelajaran 9

2 Visitasi Kepemimpinan Nasional 42

3 Proyek Perubahan 86

Evaluasi Peserta

1 Evaluasi Strategis Pemahaman dan 3 Praktik Kepemimpinan

2 Evaluasi Visitasi Kepemimpinan $\quad 0 *$

3 Evaluasi Proyek Perubahan $\quad 0 *$

4 Evaluasi Sikap Perilaku 0

Jumlah Jam Pelajaran $\quad 221$

Keterangan: (*) Jumlah JP Terintegrasi dalam mata pelatihan

Tahap (3) Pengembangan (Development) dalam melakukan langkah penge mbangan bahan pelatihan Pendidikan dan Pelatihan bagi Aparatur Sipil Negara, ada dua tujuan penting yang perlu dicapai, antara lain adalah (a) Memproduksi atau merevisi bahan pelatihan yang akan digunakan untuk mencapai tujuan pelatihan yang telah dirumuskan, (b) Memilih bahan pelatihan terbaik yang akan digunakan untuk mencapai tujuan pelatihan.

Beberapa poin yang perlu didapatkan dalam tahapan ini di antaranya : (1) Bentuk bahan pelatihan yang perlu dibuat dalam mencapai tujuan Pendidikan dan Pelatihan bagi Aparatur Sipil Negara, (2) Bentuk bahan pelatihan yang perlu dibuat dan dimodifikasi sehingga dapat memenuhi tujuan Pendidikan dan Pelatihan bagi Aparatur Sipil Negara. 
Pada Pendidikan dan Pelatihan Bagi Aparatur Sipil Negara ini, dimana pelatihan ini membekali peserta untuk memiliki kemampuan berpikir kreatif dan menerapkannya dalam melakukan inovasi pelayanan publik sesuai dengan lingkup bidang jabatan pejabat pengawas pada unit organisasi instansinya. Indikator hasil belajar setelah mengikuti Diklat ini, peserta dapat:

a. Menjelaskan substansi ceramah berpikir kreatif dalam pelayanan oleh penceramah.

b. Mempraktikan teknik-teknik berpikir kreatif dalam menghasilkan gagasan inovasi.

c. Menjelaskan strategi inovasi dalam pelayanan publik yang berperspektif Gender Equality and Social Inclusion (GESI).

d. Merancang implementasi strategi berpikir kreatif dan inovasi dalam pelayanan publik sesuai dengan tugas dan fungsi jabatannya. Dimana materi pokok Pendidikan dan Pelatihan Bagi Aparatur Sipil Negara ini pada sub materi ini terdiri atas:

1) Berpikir kreatif pelayanan.

2) Teknik-teknik berpikir kreatif dalam menghasilkan gagasan inovasi.

3) Strategi inovasi dalam pelayanan publik yang berperspektif GESI.

4) Implementasi strategi berpikir kreatif dan inovasi dalam pelayanan publik.

Tahapan

Implementasi

(Implementation): pada tahapan implementasi dalam penulisan ini merupakan tahapan untuk mengimplementasikan rancangan bahan pelatihan yang telah dikembangkan pada situasi yang nyata di kelas selama implementasi, rancangan bahan pelatihan yang telah dikembangkan diterapkan pada kondisi yang sebenarnya. Materi bahan pelatihan yang telah dikembangkan disampaikan sesuai dengan pelatihan. Setelah diterapkan dalam bentuk kegiatan pelatihan kemudian dilakukan evalusai awal untuk memberikan umpan balik pada penerapan pengembangan bahan pelatihan berikutnya. Tujuan utama dalam langkah implementasi antara lain :

a) Membimbing peserta Pendidikan dan Pelatihan bagi Aparatur Sipil Negara untuk mencapai tujuan pelatihan.

b) Menjamin terjadinya pemecahan masalah untuk mengatasi persoalan yang sebelumnya dihadapi oleh peserta Pendidikan dan Pelatihan bagi Aparatur Sipil Negara dalam proses pelatihan.

c) Memastikan bahwa pada akhir pelatihan, kemampuan peserta Pendidikan dan Pelatihan bagi Aparatur Sipil Negara meningkat.

Pada Diklat ini membekali peserta dengan kemampuan membangun tim kerja yang partisipatif dan efektif (high performance team) melalui konsep tim partisipatif dan efektif, karakteristik tim efektif dan partisipatif, dan strategi menumbuhkan tim kerja yang partisipatif dan efektif untuk pelaksanaan kegiatan pelayanan publik. Mata pelatihan ini juga membekali peserta dengan kemampuan menerapkan kepemimpinan yang melayani (servant leadership) dengan menunjukkan sikap mau mendengarkan, berempati, terbuka, dan memiliki komitmen tinggi untuk mempengaruhi/mengajak orang lain untuk memberikan pelayanan publik yang paripurna dalam pelaksanaan pekerjaan. Setelah mengikuti Diklat ini diharapkan, peserta dapat :

a. Menjelaskan pendekatan kepemimpinan dalam pelaksanaan pekerjaan.

b. Menjelaskan konsep dasar kepemimpinan dalam pelaksanaan pekerjaan.

c. Menerapkan kepemimpinan dalam pelaksanaan pekerjaan untuk memberikan pelayanan publik yang prima. 
d. Menyusun kegiatan kerjasama strategis dalam memberikan pelayanan publik yang prima.

Materi pokok untuk mata pelatihan pada sub bagian ini terdiri atas :

a. Pendekatan kepemimpinan dalam pelaksanaan pekerjaan.

b. Konsep dasar kepemimpinan dalam pelaksanaan pekerjaan.

c. Praktik baik kepemimpinan dalam pelaksanaan pekerjaan.

d. Kegiatan kerjasama strategis dalam memberikan pelayanan publik yang prima.

Tahap (5) Evaluasi (Evaluation): Evaluasi akhir Pendidikan dan Pelatihan bagi Aparatur Sipil Negara, ini dilakukan untuk memperoleh kualifikasi penilaian evaluasi peserta dengan memperhatikan keseluruhan hasil evaluasi peserta secara komprehensif melalui evaluasi penilaian akhir oleh penyelenggara Diklat. Evaluasi akhir dilakukan oleh Tim Evaluasi yang ditunjuk oleh lembaga penyelenggara pelatihan. Hasil evaluasi setelah mengikuti evaluasi ini, peserta mendapatkan kualifikasi penilaian: a) substansi; b) studi lapangan pelayanan publik; c) aksi perubahan kinerja pelayanan publik; dan d) sikap perilaku. Evaluasi merupakan langkah terakhir dari model Addie untuk memberikan nilai terhadap pengembangan bahan pelatihan. Hasil evaluasi digunakan untuk memberikan umpan balik terhadap pengembangan bahan Pendidikan dan Pelatihan bagi Aparatur Sipil Negara. Kemudian revisi dibuat sesuai dengan hasil evaluasi atau kebutuhan yang belum dapat dipenuhi oleh tujuan pengembangan Pendidikan dan Pelatihan bagi Aparatur Sipil Negara.

\section{SIMPULAN}

Model Addie merupakan suatu model yang sistematis tahapan-tahapannya, terstruktur dan berurutan. Model Addie yang diterapkan pada penelitian ini mampu mengidentifikasi pengembangan Pendidikan dan Pelatihan bagi Aparatur Sipil Negara secara mendalam.

Model Addie yang digunakan untuk mengkaji Kurikulum Pendidikan dan Pelatihan bagi Aparatur Sipil Negara dengan melalui 5 tahapan (Analysis, Design, Development, Implementation dan Evaluation), menujukkan kualitas pelatihan yang berlangsung selama ini sudah baik.

Dengan demikian, pengembangan pelatihan perlu terus dilakukan. Namun bentuk pengembanganya perlu dikaji secara ilmiah sehingga produk pengembangannya dapat menjadi solusi dalam memecahkan persoalan pelatihan.

\section{UCAPAN TERIMA KASIH}

Ucapan terimakasih penulis sampaikan kepada teman-teman widyaiswara serta Pimpinan dan jajaran pejabat structural di Badan Pengembangan Sumber Daya Manusia Provinsi Bali atas dukungan moral selama penulisan artikel ini sampai selesai.

\section{DAFTAR PUSTAKA}

[1] Ambar, T. S. dan Rosidah. 2003. Manajemen Sumber Daya Manusia. Yogyakarta : Graha Ilmu, 2003.

[2] Anwar, P. M. Manajemen Sumber Daya Manusia Perusahaan. Bandung: PT Remaja Rosdakrya, 2005.

[3] Mustofa, I. Pendidikan Islam Sebagai Institusi Politik Demokrasi Tertinggi di Indonesia. Halaqa: Islamic Education Journal 1, 2007.

[4] Sutrisno. Manajemen Sumber Daya Manusia. Jakarta: Prenada Group, 2011.

[5] Samani, M. Profesionalisasi Pendidikan. Surabaya: Unesa University Press, 2012. 
[6] Trianto. Mendesain Model Pembelajaran Inovatif Progresif : Konsep, Landasan dan Implementasi Pada Kurikulum Tingkat Satuan Pendidikan. Jakarta: Kencana Prenada Media Group, 2009.

[7] Seels, B. B. dan Richey, R. C. Instructional Technology:The Definition and Domains of The Fields. Washington D.C: AECT. 1994.

[8] Branch, R. M. Instructional Design: The ADDIE Approach. NewYork: Springer, 2009.

[9] Hadi, H. dan Agustina, S.. Pengembangan Buku Ajar Geografi Desa Kota Menggunakan Model ADDIE. Jurnal Educatio, vol. 11, no. $1,2016$. 